\title{
Inhibitory effects of L-3-phenyllacitc acid on the activity of mushnroom pholyphenol oxidase
}

\author{
Haiwei REN ${ }^{1}$, Nana DU ${ }^{1}$, Xiaoqian NIU ${ }^{1}$, Yonggang WANG ${ }^{1}$, Hui TIAN ${ }^{1}$, Yingying $\mathrm{CAO}^{1}$, Binyun $\mathrm{ZHANG}^{1}$, \\ Wenguang FAN $^{1 *}$ (1)
}

\begin{abstract}
Polyphenol oxidase is the popular enzyme involved in fruit-vegetable browning and melanin synthesis. In the present paper, L-3-phenyllactic acid, a natural bacteriostatic substance, was investigated as an inhibitor of polyphenol oxidase. The results were demonstrated that the residual enzyme activity of polyphenol oxidase decreased gradually with the increase of the concentration of L-3-phenyllactic acid. The $\mathrm{L}$ and $\Delta \mathrm{E}$ values of the reaction system increased gradually. The reversible mixed-type inhibition mode of L-3-phenyllactic acid was determined by Lineweaver Burk plot. At the same time, the results of fluorescence quenching demonstrated that L-3-phenyllactic acid was a quencher of polyphenol oxidase, and the molecular docking study provided the binding mode of L-3-phenyllactic acid and polyphenol oxidase at the molecular level. L-3-phenyllactic acid decreased the activity of polyphenol oxidase and browning of fresh-cut Agaricus Bosporus. This research first studied the inhibitory effect of L-3-phenyllactic acid on the activity of polyphenol oxidase, and would provide a theoretical foundation for the use of L-3phenyllactic acid as anti-polyphenol oxidase agents.
\end{abstract}

Keywords: L-3-phenyllactic acid; mushroom polyphenol oxidase; inhibition kinetics; fluorescence quenching; molecular docking.

Practical Application: L-3-phenyllactic acid could inhibit the activity of mushroom polyphenol oxidase.

\section{Introduction}

Polyphenol oxidase (PPO), a kind of multiple functional oxidases, which was usually founded in many organisms including animals, insects, plants and microorganisms (Li et al., 2009; Seo et al., 2003; Yin et al., 2011a). PPO is the key enzyme involved in melanin synthesis, thus determined the color of mammalian skin, hair and fruit-vegetable browning (Ciou et al., 2011; Li et al., 2010; Lee et al., 2015). Browning occurred easily in fresh-cut or minimally processed fruits and vegetables, which were due to the presence of PPO in fruits and vegetables. When fruits and vegetables were damaged, the regional and localized distribution of the cells was destroyed, let the phenolic substances contact with polyphenol oxidase, then they ware polymerized to brown pigments and accelerated the browning of fruits and vegetables (Ciou et al., 2011; Pan et al., 2011). After the treatment of fruits and vegetables, the monophenol was produced to melanin through non-enzymatic reaction in the catalysis of PPO (Ismaya et al., 2011), polymerized to brown pigments, thus accelerated the browning of fruits and vegetables. Besides enzymatic browning, $\mathrm{PPO}$ was responsible for the reduction of the nutritional quality and market value of fruits and vegetables (Zhou et al., 2016).

In recent years, many methods such as high hydrostatic pressure heating (Yi et al., 2012), heating (Gouzi et al., 2012) and organic acids have been applied to inhibit the PPO activity. Various organic acids, for example, citric acid (Liu et al., 2013), ascorbic acid (Landi et al., 2013), oxalic acid (Yoruk \& Marshall, 2010), cinnamic acid (Shi et al., 2005) and derivatives (Cui et al., 2015) have been applied in food preservation, and their inhibitory effects of the activity of PPO have been studied. It is worth noting that recent studies have found that alkyl acid substituents of benzene also have a strong inhibitory effect on PPO activity (Liu et al., 2015, 2003; Zheng et al., 2012). Benzoic acid and benzenepropanoc acid were demonstrated that they have inhibitory effects of tyrosinase monophenase and diphenolase (Liu et al., 2003; Zheng et al., 2012). L-3-phenyllactic acid (PLA), benzoic acid and benzenepropanoc acid belong to the same family of acids. In the previous studies, PLA was showed that it has strong antimicrobial activities including bacteria and fungi (Magnusson et al., 2002; Wang et al., 2009; Mu et al., 2012), and the use of PLA could keep the quality of food products. The advantages of PLA including broad antibacterial spectrum, high stability, better solubility and easy to spread in the food system began to attract people's attention, but no literature has been reported on the inhibitory effects and mechanism of PLA on the activity of mushroom polyphenol oxidase. In this paper, PLA' inhibitory effects, mechanism and type were determined. All the results laid a theoretical foundation for the further study of the interaction between PLA and PPO, and the study could supply the basis for development of original PPO inhibitors on the browning of fresh-cut fruits and vegetables. 


\section{Materials and methods}

Mushroom polyphenol oxidase (1000 U/mg) was produced in Sigma Chemical Co (St. Louis, MO, USA). PLA was purchased from Aladdin Chemicals Co (Shanghai, China). All other reagents were local and of analytical grade, solutions were prepared in double-distilled water.

\subsection{Treatment of polyphenol oxidase by PLA}

Firstly, PPO (9 mg) was dissolved in $72 \mathrm{~mL}$ phosphate buffer $(50 \mathrm{mmol} / \mathrm{L}, \mathrm{pH} 6.8)$ to a concentration of $0.125 \mathrm{mg} / \mathrm{mL}$. Secondly, PLA $(0.83 \mathrm{~g})$ was dissolved in phosphate buffer $(50 \mathrm{mmol} / \mathrm{L}, \mathrm{pH} 6.8)$ to a concentration of $50 \mathrm{mmol} / \mathrm{L}$. Last, the above PLA and PPO were mixed with phosphate buffer ( $50 \mathrm{mmol} / \mathrm{L}, \mathrm{pH} 6.8$ ). The final concentration of L-3-phenyllactic acid was $0,0.5,1.0,1.5,2.0,2.5,3.0 \mathrm{mmol} / \mathrm{L}$, respectively, and the final concentration of PPO was $0.1 \mathrm{mg} / \mathrm{mL}$. The solution was stayed at $37^{\circ} \mathrm{C}$ for $15 \mathrm{~min}$, then take out for later use.

\subsection{Determination of the maximum absorption wavelength}

The maximum absorption wavelength of the product was determined by spectrophotometry with the published reference (Buckow et al., 2009). $10 \mathrm{mmol} / \mathrm{L}$ catechol was prepared as a substrate; the buffer solution of the reaction system was $0.05 \mathrm{~mol} / \mathrm{L}$ phosphate buffer ( $\mathrm{pH}$ 6.8). The enzyme solution of $0.2 \mathrm{~mL}(0.1 \mathrm{mg} / \mathrm{mL})$ was added to the reaction system. The final concentration of the substrate was $2,4,6 \mathrm{mmol} / \mathrm{L}$, and the total volume of each reaction system was $5 \mathrm{~mL}$. Take out the reaction solution in $37^{\circ} \mathrm{C}$ water bath pot for $5 \mathrm{~min}$, and put it into ice immediately, stop the reaction. The maximum absorption wavelength $\left(\lambda_{\max }\right)$ of the product was determined by scanning every $2 \mathrm{~nm}$ in the wavelength range of $300 \sim 700 \mathrm{~nm}$. In the control group, $0.2 \mathrm{~mL}$ deionized water was used instead of PPO enzyme solution. Then, the final concentration of enzyme solution was changed to $1.5 \mathrm{mmol} / \mathrm{L}$, and the absorption peak of the product was detected. Two groups of experiments were used to determine the maximum absorption wavelength of the product formed by catechol under the catalysis of PPO. At the same time, it was determined whether the absorption peak of PPO was affected by L-3-phenyllactic acid treatment.

\subsection{PPO activity assay}

PPO activity was measured according to the published literature (Wei et al., 2009). PPO activity was determined by mixing $4.4 \mathrm{~mL}$ phosphate buffer $(50 \mathrm{mmol} / \mathrm{L}, \mathrm{pH} 6.8)$ with $0.4 \mathrm{~mL}$ catechol $(10 \mathrm{mmol} / \mathrm{L})$ in $37^{\circ} \mathrm{C}$ water bath for $3 \mathrm{~min}$. Then $0.2 \mathrm{~mL}$ enzyme solution $(0.1 \mathrm{mg} / \mathrm{mL})$, which was preheated at $37^{\circ} \mathrm{C}$ with different concentrations of L-3-phenyllactic acid, was quickly mixed, and the UV-Vis spectrophotometer kinetic module was selected. The absorbance of the reaction solution was measured at $\lambda \max$. The absorptivity was recorded once every $10 \mathrm{~s}$ and the absorbency were measured for $180 \mathrm{~s}$. The enzyme activity was calculated by the linear rising interval data of absorbance, which belonged to the initial velocity stage of enzymatic reaction. The enzyme activity of each sample was determined three times in parallel.
The enzymatic activity was expressed as the rate of enzymatic reaction, and the rate of enzymatic reaction was expressed by the increase of absorptive (A) in the unit time of (min).

$V(A / \%)=\frac{\Delta A}{t}$

The change of enzyme activity before and after treatment with inhibitor was expressed as relative activity.

Re lative activity $=\frac{\text { Activity of treated } P P O}{\text { Activity of untreated } P P O} \times 100 \%$

\subsection{Color changes in the PPO reaction system treated with PLA}

The colorimeter was used to determine the optical difference of the reaction system in which PPO was treated with different concentrations of L-3-phenyllactic acid $(0,0.5,1.0,1.5,2.0,2.5$, $3.0 \mathrm{mmol} / \mathrm{L}) .4 .4 \mathrm{~mL}$ phosphate buffer $(50 \mathrm{mmol} / \mathrm{L}, \mathrm{pH} 6.8)$ was mixed with $0.4 \mathrm{~mL}$ catechol $(10 \mathrm{mmol} / \mathrm{L})$ and placed in a constant temperature water bath of $37^{\circ} \mathrm{C}$ for $3 \mathrm{~min}$. Then it was quickly mixed with $0.2 \mathrm{~mL}$ enzyme solution $(0.1 \mathrm{mg} / \mathrm{mL})$ which was treated with different concentrations of L-3- phenyllactic acid $(0,0.5,1.0,1.5,2.0,2.5,3.0 \mathrm{mmol} / \mathrm{L})$. The reaction was kept at $37^{\circ} \mathrm{C}$ for $5 \mathrm{~min}$. L, a and b values were measured by colorimeter, the average value was taken and repeated 3 times. The value of $\Delta \mathrm{E}$ was calculated according to formula (Yang et al., 2014):

$\Delta E=\left(\left(L_{c}-L_{0}\right)^{2}+\left(a_{c}-a_{0}\right)^{2}+\left(b_{c}-b_{0}\right)^{2}\right)^{1 / 2}$.

\subsection{Kinetic analysis for the mixed-type inhibition}

The final concentration of catechol of the reaction system was $1,2,3,4,5$ and $6 \mathrm{mmol} / \mathrm{L}$, respectively. The enzymatic reaction rate of PPO enzyme treated with different concentrations of PLA was studied under different substrate concentrations. The operation steps refer to the above section (PPO activity assay).

At the same time, the kinetics parameters Km and Vmax of the reaction system were calculated by using Lineweaver-Burk double reciprocal graph. According to the change of $\mathrm{Km}$ and Vmax, the inhibition type of PLA on polyphenol oxidase was determined. The slope and intercept were used to plot the concentration of effector $(\mathrm{C} 1)$, and the inhibition constant $\left(\mathrm{K}_{\mathrm{I}}\right.$ and $\mathrm{K}_{\mathrm{IS}}$ ) was obtained.

\subsection{Fluorescence emission spectra analysis}

Fluorescence emission spectra measurement was operated according to the previous study (Zhou et al., 2016) with a small modification. Samples were scanned at 25,31 and $37^{\circ} \mathrm{C}$ using a Spectrophotometer (FSF-4500), excitation and emission slits were $5 \mathrm{~nm}$. The excitation wavelength was set at $280 \mathrm{~nm}$, and the fluorescence emission spectra were scanned from 290 to $450 \mathrm{~nm}$. Assays of $2.0-\mathrm{mL}$ final volume contained PPO $(0.1 \mathrm{mg} / \mathrm{mL})$ and PLA of different concentrations $(4.5,4.8,5.1,5.4$ and $5.7 \mathrm{mmol} / \mathrm{L}$ ). Each measurement result was recorded in 3 times. The data of fluorescence quenching were used to analyze to the equilibrium between bound and free molecules. 


\subsection{Molecular docking}

Molecular docking study was applied to investigate the binding mode between the compound and PPO activity of agaricus bisporus using Autodock vina 1.1.2 (Trott \& Olson, 2010). The three-dimensional (3D) coordinate of the PPO (PDB ID: 2Y9X) was downloaded from RCSB Protein Data Bank (Walter et al., 2003). The 2D structure of the compound was drawn by ChemBioDraw Ultra 14.0 and converted to 3D structure by ChemBio3D Ultra 14.0 software. The Auto DockTools 1.5.6 package (Morris et al., 2009; Sanner, 1999) was employed to generate the docking input files. The ligand was prepared for docking by merging non-polar hydrogen atoms and defining rotatable bonds. According to the location of the co-crystallized ligand tropolone, the search grid of the tyrosinase binding site was identified as center_x: -10.044, center_y: -28.706, and center_z: -43.443 with dimensions size_x: 15, size_y: 15, and size_z: 15. In order to increase the docking accuracy, the value of exhaustiveness was set to 20. For Vina docking, the default parameters were used if it was not mentioned. The best-scoring pose as judged by the Vina docking score was chosen and visually analyzed using PyMoL 1.7.6 software. By re-docking tropolone with these settings, its co-crystallized conformation was reproduced approximately (RMSD: $0.98 \AA$ ).

\subsection{Change of polyphenol oxidase activity and browning of fresh-cut Agaricus Bosporus}

Agaricus Bosporus was peeled cut into even pieces of $5 \mathrm{~mm}$ each and treated with two concentrations of PLA (0.03 and $0.05 \mathrm{~mol} / \mathrm{L}$ ) solution for five minutes; control samples were treated in distilled water. After drying naturally for $20 \mathrm{~min}$ at room temperature, 40 pieces were randomly packed into food polypropylene square boxes $(15 \mathrm{~cm} \times 10 \mathrm{~cm} \times 8 \mathrm{~cm})$ with 6 round holes (diameter $=5 \mathrm{~mm}$ ). The pieces were stored at $4{ }^{\circ} \mathrm{C}$ and analyzed periodically for 12 days of storage.

$1 \mathrm{~g}$ of Agaricus Bosporus were homogenized in $2 \mathrm{~mL}$ phosphate buffer containing PVPP (4\%), PEG ( $1 \mathrm{~mol} / \mathrm{L})$ and Triton X-100 (1\%), the filtrate was centrifuged at $10,000 \mathrm{~g}$ for $10 \mathrm{~min}$ at $4{ }^{\circ} \mathrm{C}$. The supernatant was used for the enzyme analysis. The PPO activity was measured by the increase in absorbance at $420 \mathrm{~nm}$. One unit of enzyme activity was confirmed as the increase in absorbance of 0.01 per min under the conditions of the assay.

The surface color change of slices was assessed using a colorimeter (Model CR-300, Minolta, Tokyo, Japan), which showed the $\mathrm{L}$, $\mathrm{a}$ and $\mathrm{b}$ values by the CIE color. The measured position should not be a fruit-stalk of Agaricus Bosporus. L values were used as the evaluation index of the surface color of browning.

\subsection{Statistical analysis}

The programs were drawn by prism 6 . The data were statistically analyzed by analysis of variance in the SPSS 20. All experiments were operated in three times. Data were listed as means \pm SD. The mean separations were analyzed using Duncan's multiple range test and differences were considered to be statistically significant at $P<0.05$.

\section{Results and discussion}

The spectral scanning diagram of PPO without and with PLA participated in the reaction system was shown (Figure 1 and B). From Figure 1A and B, we found the products have the maximum absorption peak at the wavelength of 403-410 nm, and the addition of PLA did not affect the absorption peak of the products (Figure 1A and B). With the increased of substrate concentration, the absorption value of the product increased. The amount of products in the reaction system with PLA (Figure 1B) was lower than that in the reaction system without PLA (Figure 1A), which indicated that the reaction rate was also lower than that of the control group. It could be concluded that the amount of products in the reaction system in the certain reaction time were stable, and the addition of PLA reduced the amount of the products, and had no effect on the maximum absorption peak of the products.

The inhibitory effects of PLA on PPO activity were researched. As shown in Figure 1C, the relative activity of PPO decreased with increasing concentrations of PLA. The $\mathrm{IC}_{50}$ for inhibition of PPO activity by PLA was determined to be $1.25 \mathrm{mmol} / \mathrm{L}$. When the final concentration of PLA was $0 \sim 1.5 \mathrm{mmol} / \mathrm{L}$, the residual activity of PPO decreased rapidly. When the concentration of PLA was $1.5 \mathrm{mmol} / \mathrm{L}$, the relative activity of PPO was $42.59 \%$. When the concentration of PLA was $3.0 \mathrm{mmol} / \mathrm{L}$, the relative activity of PPO was $27.62 \%$, and the activity of PPO was very low.

When the concentration, reaction time and amount of added enzyme in the reaction system were fixed, the change of $\mathrm{L}$ values could determine the inhibitory effect of different concentrations of PLA on PPO activity. As shown in Figure 1D, with the increase of the concentration of PLA, the L values of the reaction system increased obviously, it indicated that the browning degree of the reaction system decreased gradually. When the concentration of PLA was $3.0 \mathrm{mmol} / \mathrm{L}$, the $\mathrm{L}$ value of the reaction system was 25.76 , which indicated PPO activity in the reaction was low.

$\Delta \mathrm{E}$ values could show the color difference of reaction system integrated optical value. When $\Delta \mathrm{E}$ value $>3$, the color difference was very significant. From Figure 1E, with the increase of the concentration of PLA, the $\Delta \mathrm{E}$ values of the reaction system increased, indicating that the color difference between the experimental group (with PLA treatment of enzyme in the reaction system) and the control group (without PLA treatment of enzyme in the reaction system) increased gradually. When the concentration of PLA was $0.5 \mathrm{mmol} / \mathrm{L}$, the $\Delta \mathrm{E}$ value of the reaction system was 0.89 , and when the concentration of PLA was $1.5 \mathrm{mmol} / \mathrm{L}$, the $\Delta \mathrm{E}$ value of the reaction system was 3.50 , which showed the color difference between the experimental group and the control group was very high. When the concentration of PLA was $3.0 \mathrm{mmol} / \mathrm{L}$, the $\Delta \mathrm{E}$ value of the reaction system was 5.91, indicating the effect of Inhibiting browning was obvious. In sum, with the increase of the concentration of PLA, the L and $\Delta E$ values of the reaction system increased gradually. It was illustrated that the activity of PPO was inhibited by PLA, and the degree of browning of reaction system was reduced.

The kinetic expression of PLA on PPO activity was studied, and the results of inhibition kinetics were showed in Figure 2 

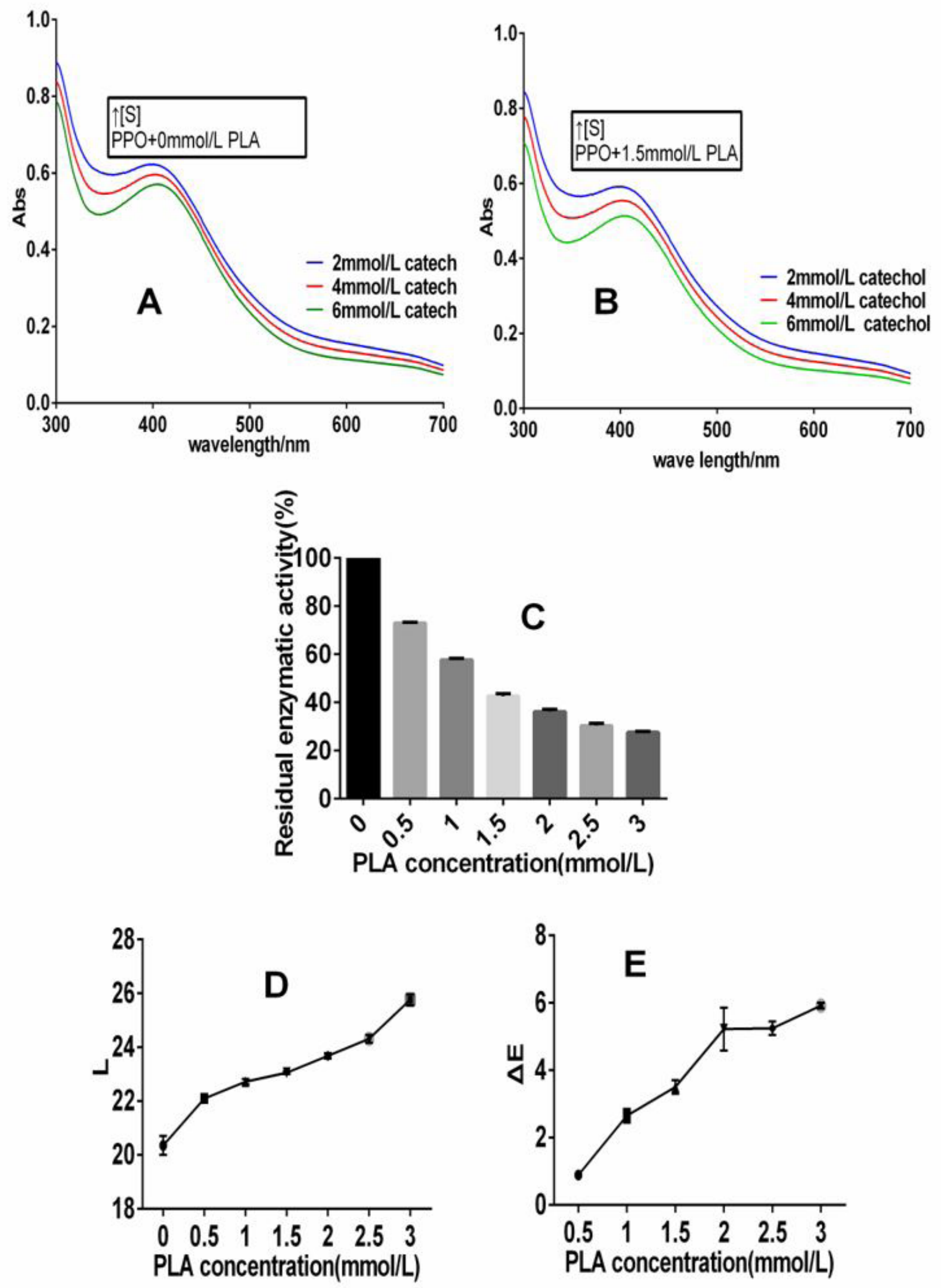

Figure 1. Inhibitory effects of PLA on the activity of PPO. (A-B) The maximum absorption wavelength of the generated product from the reaction of PPO and catechol; (C) Effect of PLA on PPO activity; (D-E) The L and $\triangle \mathrm{E}$ values of PPO enzymatic reaction system under different concentrations of PLA treatments. 

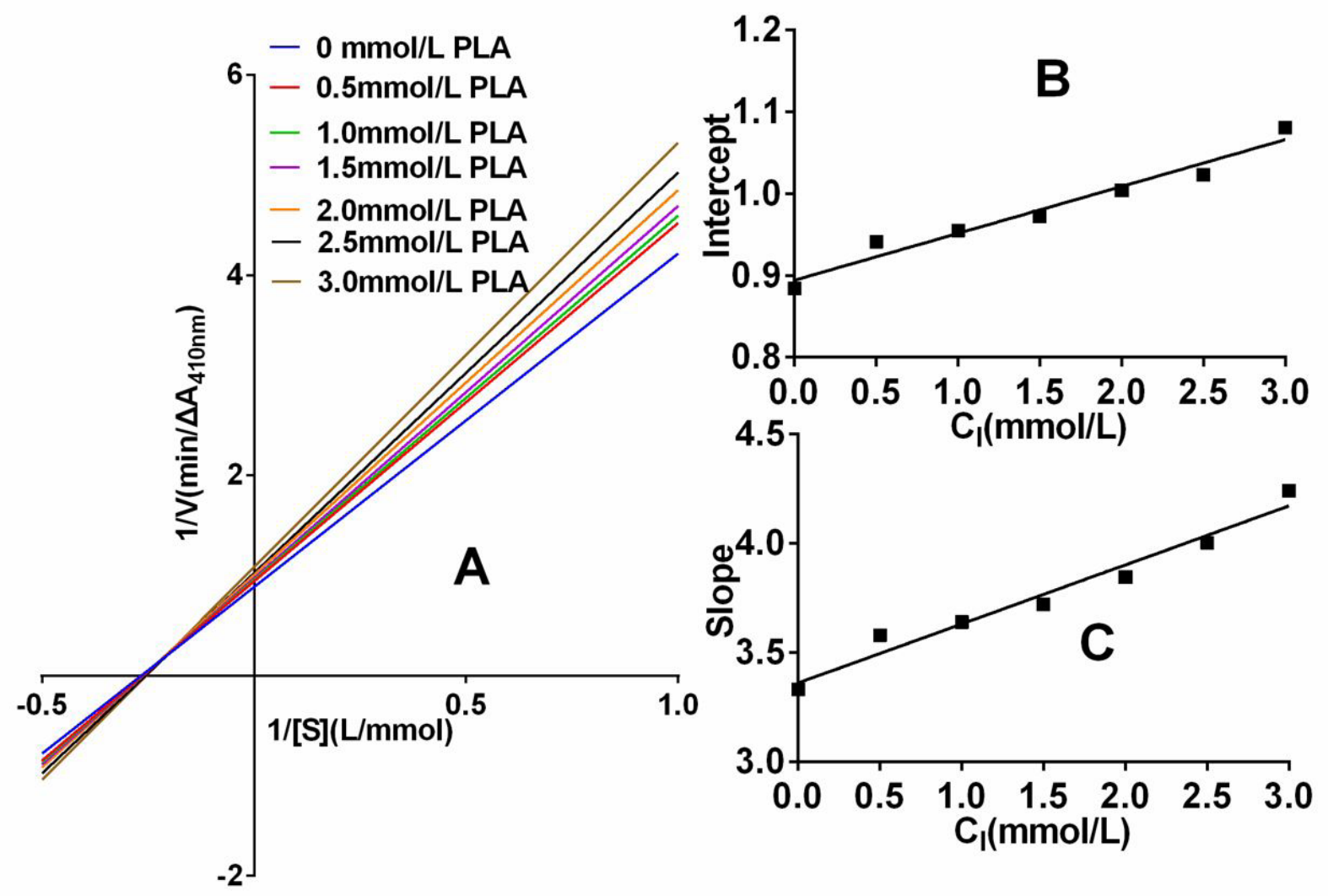

Figure 2. Determination of the inhibitory type and inhibition constants of PLA on the activity of PPO. (A) Lineweaver-Burk plots for inhibition of PLA on PPO. The concentrations of inhibitor for lines are 0, 0.5, 1.0, 1.5, 2.0, 2.5, $3.0 \mathrm{mmol} / \mathrm{L}$, respectively; (B) The plot of intercept versus the concentration of PLA determining the inhibition constants $\mathrm{K}_{\mathrm{IS}} ;(\mathrm{C})$ The plot of slope versus the concentration of PLA for determining the inhibition constants $\mathrm{K}_{\mathrm{I}}$.

and Table 1. It showed that PLA was a reversible mixed-type inhibitor. The $\mathrm{K}_{\mathrm{I}}$ and $\mathrm{K}_{\mathrm{IS}}$ were $12.42 \mathrm{mmol} / \mathrm{L}$ and $17.45 \mathrm{mmol} / \mathrm{L}$, respectively, manifesting that the inhibition intensity of PLA on enzyme-substrate complex was greater than that on free enzyme.

In this part, we chose fluorescence emission spectra measurement to further study the interaction between PPO and PLA. The fluorescence emission spectra of PPO before and after the addition of PLA at different concentrations were shown in Figure $3 \mathrm{~A}-\mathrm{C}\left(25,31,37^{\circ} \mathrm{C}\right)$. PPO had strong fluorescence at peak wavelength $342 \mathrm{~nm}$. The fluorescence intensity of PPO decreased with increase of PPO concentrations, and the shift of the maximum peak was not significant. These results showed that PLA might interact with PPO, covered some color base of PPO and then quenched the intrinsic fluorescence.

The PLA was docked into the binding site of PPO and the result was shown in Figure 4. The evaluated binding energy between PPO and PLA was $-5.8 \mathrm{kcal} / \mathrm{mol}$. The compound PLA adopted a compact conformation to bind in the site of PPO (Figure 4). The PLA was located at the hydrophobic site, surrounded by the residues Phe-264, Met-280, Val-283 and Ala-286, forming a stable hydrophobic binding. Detailed analysis showed that the phenyl group of the PLA formed $\mathrm{CH}-\pi$ interaction with the side chain of the residue Phe-264. Importantly, one key chelation was observed between the PLA and the $\mathrm{Cu}$ atom, with the bond length of $3.5 \AA$, which was the main interaction between PLA and PPO (Figure 4). All these interactions helped PLA to anchor in the binding site of PPO.

Besides the effect of PLA on commercial PPO, the effect of PLA on fresh-cut Agaricus Bosporus was assessed to analyze the PPO inhibitory effect. Figure 5 was showed the inhibitory effects of PLA on browning and PPO activity in fresh-cut Agaricus Bosporus. Figure 5A and B depicted the lighter degree of browning from PLA treated slices when compared to the distilled water-treated samples. The PPO activity of distilled water-treated Agaricus Bosporus slices remained higher than did the PLA treatment (Figure 5B and C). Statistical analysis revealed that 0.03 and $0.05 \mathrm{~mol} / \mathrm{L}$ PLA -treated slices showed no significant difference. PPO activity was decreased and the anti-browning effect of PLA was showed. Fresh-cut operation could break cell regionalization, cause the reaction of PPO and substrate, and produce melanin. PLA inhibited polyphenol oxidase activity and browning degree, which could extend the shelf life of fresh-cut Agaricus Bosporus.

Polyphenol oxidase (PPO) is a type-3 copper-containing oxidase (Goldfeder et al., 2013). Many methods have been chose to inhibit PPO activity, but some inhibitors may give rise to health problems (Nyawali et al., 2015). Thus, the safety of inhibitors gets more and more attention, developing new 
Table 1. The kinetic parameters and regression equation of PLA inhibition on PPO.

\begin{tabular}{cccc}
\hline PLA $(\mathrm{mmol} / \mathrm{L})$ & PPO regression equation of PLA treatment & $\mathrm{Km}(\mathrm{mmol} / \mathrm{L})$ & $\mathrm{Vmax}(\mathrm{A} / \mathrm{min})$ \\
\hline 0.5 & $1 / \mathrm{V}=3.5799 /[\mathrm{S}]+0.9415$ & 3.802 & 1.062 \\
1.0 & $1 / \mathrm{V}=3.6399 /[\mathrm{S}]+0.9552$ & 3.811 & 1.047 \\
1.5 & $1 / \mathrm{V}=3.7189 /[\mathrm{S}]+0.972$ & 3.826 & 1.029 \\
2.0 & $1 / \mathrm{V}=3.8461 /[\mathrm{S}]+1.0041$ & 3.830 & 0.996 \\
2.5 & $1 / \mathrm{V}=4.0035 /[\mathrm{S}]+1.0231$ & 3.913 & 0.977 \\
3.0 & $1 / \mathrm{V}=4.2417 /[\mathrm{S}]+1.0808$ & 3.925 & 0.925 \\
\hline
\end{tabular}

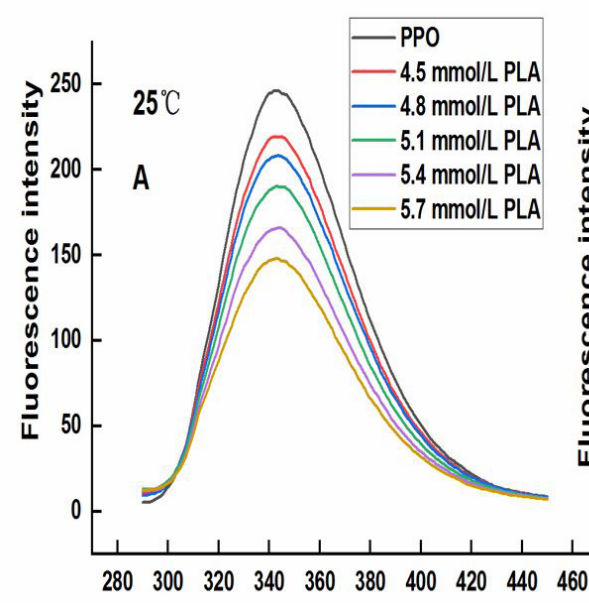

Wavelength $(\mathrm{nm})$

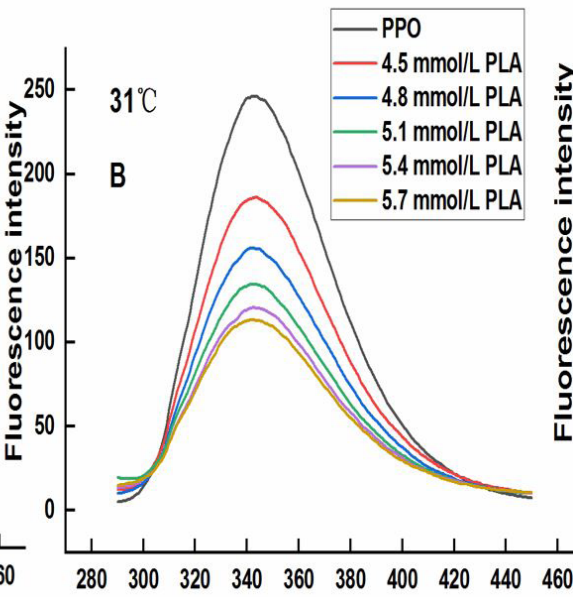

Wavelength (nm)

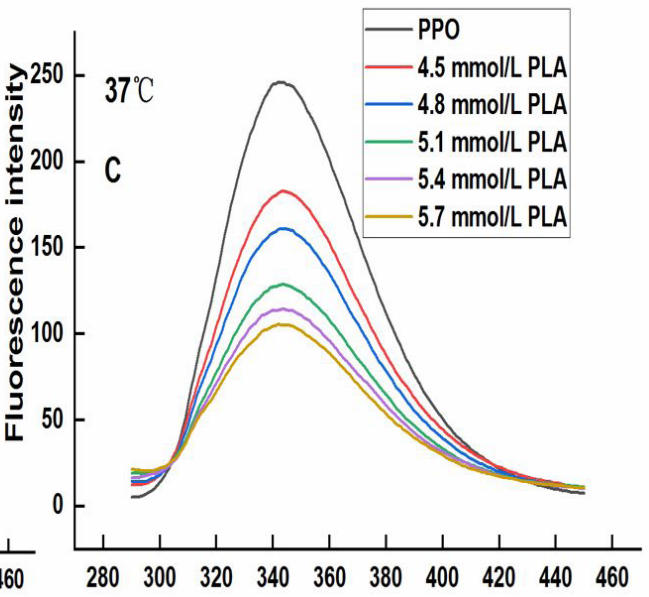

Wavelength (nm)

Figure 3. Changes in intrinsic PPO fluorescence at different temperature of PLA ((A) $25^{\circ} \mathrm{C}$; (B) $31^{\circ} \mathrm{C}$; (C) $\left.37^{\circ} \mathrm{C}\right)$ ).

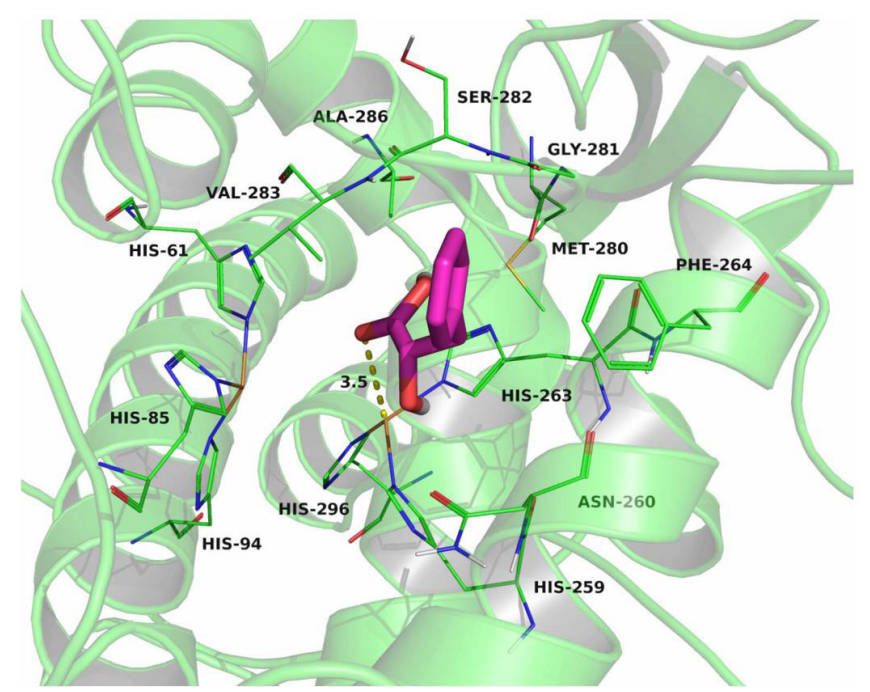

Figure 4. L-3-phenyllactic acid was docked into the binding site of PPO.

candidates is imperative. As the newest bacteriostatic agent, many studies have been shown that PLA has antimicrobial activities and the application value of kept the quality of food products (Magnusson et al., 2002; Wang et al., 2009; Mu et al., 2012). PLA is harmless to humans, animals and plants, so developing the new potential value of PLA are very important, which can improve the application value of PLA on actual production. Recent studies have found benzoic acid and benzenepropanoc acid have a strong inhibitory effect on PPO (Liu et al., 2003; Zheng et al., 2012), and PLA, benzoic acid and benzenepropanoc acid belong to alkyl acid substituents of benzene, here, we're wondering whether PLA can inhibit PPO activity? Based on the above two points, this paper studied the inhibitory effects of PLA on PPO.

The results in this study showed that PLA could inhibit the activity of mushroom polyphenol oxidase. The $\mathrm{IC}_{50}$ for inhibition of PPO activity by PLA was $1.25 \mathrm{mmol} / \mathrm{L}$. We concluded PLA was a reversible mixed-type inhibitor from inhibition kinetics analysis. PLA behaved in same manner as benzenepropanoc acid on PPO activity (Zheng et al., 2012). It was found that these alkyl acid substituents of benzene had inhibitory effect on PPO activity through literature review. Many studies reported that some inhibitors such as isophthalic acid (Si et al., 2011), tricin (Mu et al., 2013), morin (Wang et al., 2014), and cinnamic acid (Zhou et al., 2016) interacted with PPO with the quenching of fluorescence intensity, but the difference among the effect of them was obvious. From analysis the results of fluorescence quenching of PPO with PLA, we found PLA indeed interacted with PPO. Although PLA could induce the decrease of fluorescence intensity, whether they acted in a static manner or dynamic manner will 


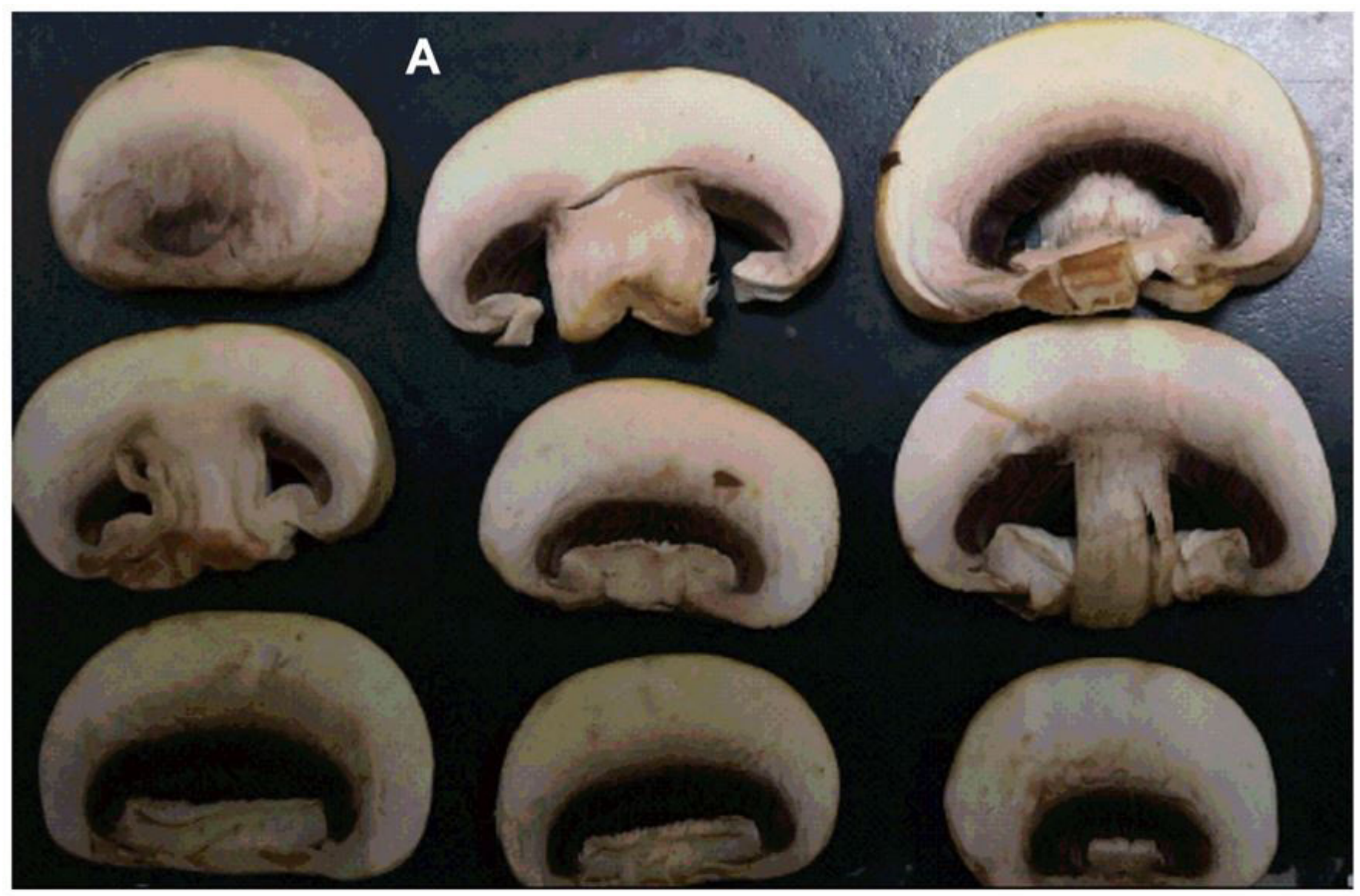

Disstilled water

$0.03 \mathrm{~mol} / \mathrm{L}$ PLA

$0.05 \mathrm{~mol} / \mathrm{L}$ PLA
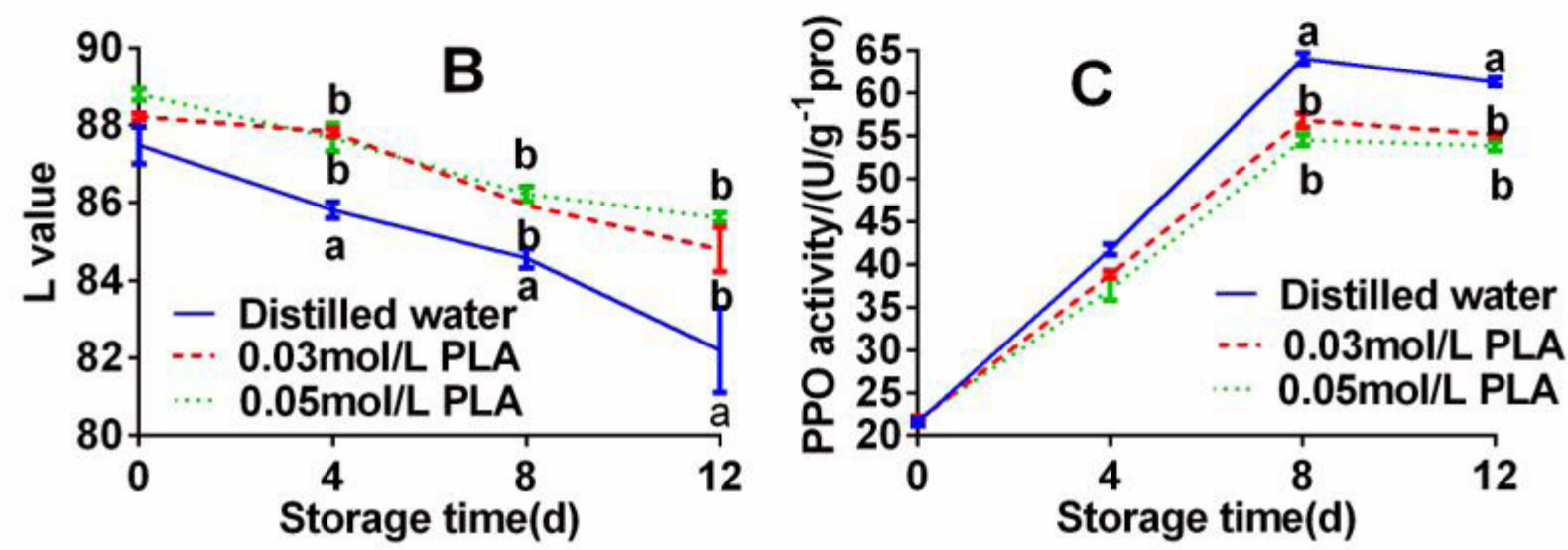

Figure 5. (A) Effect of PLA on appearance of fresh-cut Agaricus Bosporus; (B) Effect of PLA on L values of the surface of fresh-cut Agaricus Bosporus, means in the same storage time with the same letter are not significantly $(P<0.05)$; $(\mathrm{C})$ Effect of PLA on polyphenol oxidase activity in fresh-cut Agaricus Bosporus, means in the same storage time with the same letter are not significantly $(P<0.05)$.

require further study. The molecular docking results listed the lowest binding energy between PLA and PPO was $-5.8 \mathrm{kcal} / \mathrm{mol}$, and PLA participated in PPO inhibition in a mixed manner rather than simple copper chelation. This result was consistent with previous studies of inhibitors docking with PPO (Wei-Jiang et al., 2012;
Yin et al., 2011b; Zhou et al., 2016). Besides the effect of PLA on commercial PPO, the effect of PLA on fresh-cut Agaricus Bosporus was also studied. Practically PLA inhibited the polyphenol oxidase activity of fresh-cut Agaricus Bosporus, and also delayed the browning of fresh-cut Agaricus Bosporus. 


\section{Conclusion}

In this study, the inhibitory effects of PLA on the activity of mushroom polyphenol oxidase were investigated. PLA was a reversible mixed-type inhibitor on PPO activity. The $\mathrm{K}$, and $\mathrm{K}_{\text {Is }}$ were $12.42 \mathrm{mmol} / \mathrm{L}$ and $17.45 \mathrm{mmol} / \mathrm{L}$ respectively. PLA might interact with PPO and quench the fluorescence intensity. Docking results showed that PLA participated in PPO inhibition in a mixed manner rather than simple copper chelation. In practice, PLA reliably inhibited the activity of polyphenol oxidase and browning degree of fresh-cut Agaricus Bosporus. This research first studied the inhibitory effect of L-3-phenyllactic acid on the activity of polyphenol oxidase, and this study could provide a theoretical foundation for application of the alkyl acid substituents of benzene on PPO inhibition.

\section{Acknowledgements}

This research was supported by the Chinese National Natural Science Foundation (31960491) and Research Project of Gansu Provincial Department of Education (2018A-013).

\section{References}

Buckow, R., Weiss, U., \& Knorr, D. (2009). Inactivation kinetics of apple polyphenol oxidase in different pressure-temperature domains. Innovative Food Science \& Emerging Technologies, 10(4), 441-448. http://dx.doi.org/10.1016/j.ifset.2009.05.005.

Ciou, J. Y., Lin, H. H., Chiang, P. Y., Wang, C. C., \& Charles, A. L. (2011). The role of polyphenol oxidase and peroxidase in the browning of water caltrop pericarp during heat treatment. Food Chemistry, 127(2), 523-527. http://dx.doi.org/10.1016/j.foodchem.2011.01.034. PMid:23140696.

Cui, Y., Liang, G., Hu, Y. H., Shi, Y., Cai, Y. X., Gao, H. J., Chen, Q. X., \& Wang, Q. (2015). Alpha-substituted derivatives of cinnamaldehyde as tyrosinase inhibitors: inhibitory mechanism and molecular analysis. Journal of Agricultural and Food Chemistry, 63(2), 716-722. http:// dx.doi.org/10.1021/jf505469k. PMid:25547255.

Goldfeder, M., Kanteev, M., Adir, N., \& Fishman, A. (2013). Influencing the monophenolase/diphenolase activity ratio in tyrosinase. Biochimica et biophysica acta, 1834(3), 629-633. http://dx.doi.org/10.1016/j. bbapap.2012.12.021. PMid:23305929.

Gouzi, H., Depagne, C., \& Coradin, T. (2012). Kinetics and thermodynamics of the thermal inactivation of polyphenol oxidase in an aqueous extract from Agaricus bisporus. Journal of Agricultural and Food Chemistry, 60(1), 500-506. http://dx.doi.org/10.1021/jf204104g. PMid:22148350.

Ismaya, W. T., Rozeboom, H. J., Weijn, A., Mes, J. J., Fusetti, F., Wichers, H. J., \& Dijkstra, B. W. (2011). Crystal structure of Agaricus bisporus mushroom tyrosinase: identity of the tetramer subunits and interaction with tropolone. Biochemistry, 50(24), 5477-5486. http://dx.doi.org/10.1021/bi200395t. PMid:21598903.

Landi, M., Degl'Innocenti, E., Guglielminetti, L., \& Guidi, L. (2013). Role of ascorbic acid in the inhibition of polyphenol oxidase and the prevention of browning in different browningsensitive Lactuca sativa var. capitata (L.) and Eruca sativa (Mill.) stored as fresh-cut produce. Journal of the Science of Food and Agriculture, 93(8), 1814-1819. http://dx.doi.org/10.1002/jsfa.5969. PMid:23184255.
Lee, S.-M., Chen, Y.-S., Lin, C.-C., \& Chen, K.-H. (2015). Hair dyes resorcinol and lawsone reduce production of melanin in melanoma cells by tyrosinase activity inhibition and decreasing tyrosinase and microphthalmia-associated transcription factor (MITF) expression. International Journal of Molecular Sciences, 16(1), 1495-1508. http:// dx.doi.org/10.3390/ijms16011495. PMid:25584612.

Li, S. B., Xue, Y., Lv, X. Y., Nie, H. L., Zhu, L. M., Zhang, H. T., Qiu, T., \& Zhou, L. M. (2009). In vitro effect of ozagrel on mushroom tyrosinase. The Protein Journal, 28(3-4), 182-188. http://dx.doi. org/10.1007/s10930-009-9182-3. PMid:19507014.

Li, Z.-C., Chen, L.-H., Yu, X.-J., Hu, Y.-H., Song, K.-K., Zhou, X.W., \& Chen, Q.-X. (2010). Inhibition Kinetics of Chlorobenzaldehyde Thiosemicarbazones on Mushroom Tyrosinase. Journal of Agricultural and Food Chemistry, 58(23), 12537-12540. http://dx.doi.org/10.1021/ jf1033625. PMid:21062043.

Liu, W., Zou, L. Q., Liu, J. P., Zhang, Z. Q., Liu, C. M., \& Liang, R. H. (2013). The effect of citric acid on the activity, thermodynamics and conformation of mushroom polyphenoloxidase. Food Chemistry, 140(1-2), 289-295. http://dx.doi.org/10.1016/j.foodchem.2013.02.028. PMid:23578645.

Liu, X. D., Huang, H., \& Chen, Q. X. (2003). Studies on inhibitory effects of benzoic acid on mushroom tyrosinase. Journal of Xiamen University (Natural Science), 2003 (1), 102-106.

Liu, X., Jia, Y. L., Chen, J. W., Liang, G., Guo, H. Y., Hu, Y. H., Shi, Y., Zhou, H. T., \& Chen, Q. X. (2015). Inhibition effects of benzylideneacetone, benzylacetone, and 4-phenyl-2-butanol on the activity of mushroom tyrosinase. Journal of Bioscience and Bioengineering, 119(3), 275-279. http://dx.doi.org/10.1016/j.jbiosc.2014.08.014. PMid:25441446.

Magnusson, J., Jonsson, H., Schnürer, J., \& Roos, S. (2002). Weissella soli sp. nov., a lactic acid bacterium isolated from soil. International Journal of Systematic and Evolutionary Microbiology, 52(Pt 3), 831834. PMid:12054246.

Morris, G. M., Ruth, H., William, L., Sanner, M. F., Belew, R. K., Goodsell, D. S., \& Olson, A. J. (2009). AutoDock4 and AutoDockTools4: Automated docking with selective receptor flexibility. Journal of Computational Chemistry, 30(16), 2785-2791. http://dx.doi. org/10.1002/jcc.21256. PMid:19399780.

Mu, W., Yu, S., Zhu, L., Zhang, T., \& Jiang, B. (2012). Recent research on 3-phenyllactic acid, a broad-spectrum antimicrobial compound. Applied Microbiology and Biotechnology, 95(5), 1155-1163. http:// dx.doi.org/10.1007/s00253-012-4269-8. PMid:22782253.

Mu, Y., Li, L., \& Hu, S. Q. (2013). Molecular inhibitory mechanism of tricin on tyrosinase. Spectrochimica Acta. Part A, Molecular and Biomolecular Spectroscopy, 107(7), 235-240. http://dx.doi. org/10.1016/j.saa.2013.01.058. PMid:23434549.

Nyawali, B., Chungu, D., Chisha-Kasumu, E., Vinya, R., Chileshe, F., \& Ng'Andwe, P. (2015). Enzymatic browning reduction in white cabbage (Brassica oleracea) using honey: Does honey color matter? Lebensmittel-Wissenschaft + Technologie, 61(2), 543-549. http:// dx.doi.org/10.1016/j.lwt.2014.12.006.

Pan, Z. Z., Li, H. L., Yu, X. J., Zuo, Q. X., Zheng, G. X., Shi, Y., Liu, X., Lin, Y. M., Liang, G., Wang, Q., \& Chen, Q. X. (2011). Synthesis and antityrosinase activities of alkyl 3,4-dihydroxybenzoates. Journal of Agricultural and Food Chemistry, 59(12), 6645-6649. http://dx.doi. org/10.1021/jf200990g. PMid:21595493.

Sanner, M. F. (1999). Python: a programming language for software integration and development. Journal of Molecular Graphics \& Modelling, 17(1), 57-61. PMid:10660911.

Seo, S. Y., Sharma, V. K., \& Sharma, N. (2003). Mushroom tyrosinase: recent prospects. Journal of Agricultural and Food Chemistry, 51(10), 2837-2853. http://dx.doi.org/10.1021/jf020826f. PMid:12720364. 
Shi, Y., Chen, Q. X., Wang, Q., Song, K. K., \& Qiu, L. (2005). Inhibitory effects of cinnamic acid and its derivatives on the diphenolase activity of mushroom (Agaricus bisporus) tyrosinase. Food Chemistry, 92(4), 707-712. http://dx.doi.org/10.1016/j.foodchem.2004.08.031.

Si, Y. X., Yin, S. J., Park, D., Chung, H. Y., Yan, L., Lü, Z. R., Zhou, H. M., Yang, J. M., Qian, G. Y., \& Park, Y. D. (2011). Tyrosinase inhibition by isophthalic acid: kinetics and computational simulation. International Journal of Biological Macromolecules, 48(4), 700-704. http://dx.doi.org/10.1016/j.ijbiomac.2011.02.015. PMid:21371502.

Trott, O., \& Olson, A. J. (2010). AutoDock Vina: improving the speed and accuracy of docking with a new scoring function, efficient optimization, and multithreading. Journal of Computational Chemistry, 31(2), 455-461. PMid:19499576.

Walter, H., Tom, K., Joel, S., \& Helen, M. B. (2003). RSB Protein Date Bank. Retrieved from http://www.rcsb.org/.2003/2019-10-20.

Wang, J. P., Yoo, J. S., Lee, J. H., Zhou, T. X., Jang, H. D., Kim, H. J., \& Kim, I. H. (2009). Effects of phenyllactic acid on production performance, egg quality parameters, and blood characteristics in laying hens. Journal of Applied Poultry Research, 18(2), 203-209. http://dx.doi.org/10.3382/japr.2008-00071.

Wang, Y., Zhang, G., Yan, J., \& Gong, D. (2014). Inhibitory effect of morin on tyrosinase: Insights from spectroscopic and molecular docking studies. Food Chemistry, 163(3), 226-233. http://dx.doi. org/10.1016/j.foodchem.2014.04.106. PMid:24912720.

Wei, L., Liu, J., Liu, C., Zhong, Y., Liu, W., \& Jie, W. (2009). Activation and conformational changes of mushroom polyphenoloxidase by high pressure microfluidization treatment. Huanjing Kexue Yanjiu, 10(2), 142-147.

Wei-Jiang, H., Li, Y., Daeui, P., Hyoung Oh, J., Hae Young, C., JunMo, Y., \& Guo-Ying, Q. (2012). Kinetic, structural and molecular docking studies on the inhibition of tyrosinase induced by arabinose. International Journal of Biological Macromolecules, 50(3), 694-700. http://dx.doi.org/10.1016/j.ijbiomac.2011.12.035. PMid:22245359.
Yang, T., Bai, Y., Wu, F., Yang, N., Zhang, Y., Bashari, M., Jin, Z., \& Xu, X. (2014). Combined effects of glucose oxidase, papain and xylanase on browning inhibition and characteristics of fresh whole wheat dough. Journal of Cereal Science, 60(1), 249-254. http://dx.doi. org/10.1016/j.jcs.2014.04.002.

Yi, J., Jiang, B., Zhang, Z., Liao, X., Zhang, Y., \& Hu, X. (2012). Effect of ultrahigh hydrostatic pressure on the activity and structure of mushroom (Agaricus bisporus) polyphenoloxidase. Journal of Agricultural and Food Chemistry, 60(2), 593-599. http://dx.doi. org/10.1021/jf203405u. PMid:22136649.

Yin, S. J., Si, Y. X., \& Qian, G. Y. (2011a). Inhibitory effect of phthalic Acid on tyrosinase: the mixed-type inhibition and docking simulations. Enzyme Research, 2011, 1-7. http://dx.doi.org/10.4061/2011/294724. PMid:21637327.

Yin, S. J., Si, Y. X., Chen, Y. F., Qian, G. Y., Lü, Z. R., Oh, S., Lee, D. Y., Lee, S., Yang, J. M., Lee, D. Y., \& Park, Y. D. (2011b). Mixed-Type Inhibition of Tyrosinase from Agaricus bisporus by Terephthalic Acid: Computational Simulations and Kinetics. The Protein Journal, 30(4), 273-280. http://dx.doi.org/10.1007/s10930-011-9329-x. PMid:21562848.

Yoruk, R., \& Marshall, M. R. (2010). A survey on the potential mode of inhibition for oxalic acid on polyphenol oxidase. Journal of Food Science, 68(8), 2479-2485. http://dx.doi.org/10.1111/j.1365-2621.2003. tb07049.x.

Zheng, C. Y., Guo, Y. J., Liang, G., Zuo, Q. X., Yang, M. H., Li, S., \& Chen, Q. X. (2012). Studies on inhibitory effects of benzenepropanoic acid on mushroom tyrosinase activity. Journal of Xiamen University (Natural Science), 123-126.

Zhou, L., Liu, W., Xiong, Z., Zou, L., Chen, J., Liu, J., \& Zhong, J. (2016). Different modes of inhibition for organic acids on polyphenoloxidase. Food Chemistry, 199, 439-446. http://dx.doi. org/10.1016/j.foodchem.2015.12.034. PMid:26775993. 